\begin{tabular}{|l|l|c|l|}
\hline & & $110-117$ & Hannover 1998 \\
\hline
\end{tabular}

\title{
Havara on Cyprus - a surficial calcareous deposit
}

\author{
WOLFGANG SCHIRMER*) \\ Havara, talus, colluvial deposit, kafkalla, caliche, fossil soils, ${ }^{44} \mathrm{C}$ data, \\ Middle Würmian, Cyprus
}

\begin{abstract}
Havara is a local name of a surficial, soft, porous, white to buff, carbonaceous, clastic rock of Quaternary age widely spread in Cyprus. Its grain size varies from predominant silt to pebbles. It is bound to the surficial outcrop of chalky and marly deposits dating from Upper Maastrichtian through Quaternary. Genetically it is slope debris accumulated at the slope toes, concentrated to debris cones at the exits of dales and small valleys or spread as thin cover bed over even or gently inclined surfaces. It has been deposited preferably as colluvium but also by solifluction. Rock fall as well as eolian origin is not considerable. The Kalavasós Márcou Site exhibits havara rhythmically bedded by fining upward sequences each ending with fossil soil (calcic regosol). ${ }^{14} \mathrm{C}$ ages of charcoal dated two of the soils to 31.970 and 27.440 a BP, i. e. Middle Würmian 4. Similar rhythmicity is known from loess sequences in Central Europe, thus giving evidence that the climatic rhythmicity worldwide known is likewise reflected within the debris processes of the eastern Mediteranean. The rhythmical interbedding of havara with soil formations gives evidence of less vegetated landscapes during main phases of havara formation.

In contrast to havara, kafkalla is the result of soil forming processes. Descendent, ascendent and lateral intrasolum lime transport forms hard crusting of the surface (caliche).
\end{abstract}

\section{[Havara auf Zypern - eine terrestrische kalkige Deckschicht]}

Kurzfassung: Havara ist eine Lokalbezeichnung für ein gelblich-weißes, hoch kalkhaltiges, klastisches, quartärzeitliches Lockergestein mit weiter Verbreitung auf Zypern. Die Korngröße ist vorwiegend Silt, reicht aber bis Kiesgröße. Der Steinanteil wechselt örtlich bedingt. Regional ist Havara an den Ausstrich kalkig-mergeliger mariner Gesteine des Oberen Maastrichts bis zum Pliozän gebunden, die große Teile Zyperns einnehmen. Genetisch ist Havara Hangschutt mit Anhäufung am Hangfuß. Am Ausgang von Hanghohlformen, Hangrissen und Tälchen ist er zu Schuttkegeln angehäuft und enthält dann vermehrt gröbere Steinanteile. Ebene oder schwach geneigte Flächen werden von dünneren, eher feinkörnigen Kalkstaub- und Kalksanddecken überkleidet. Vorwiegender Transporttyp ist deluvial durch Abspülung am Hang. Ungeregelte Massen mit groben Gesteinsanteilen müssen auch solifluktiv bewegt worden sein. Unter anthropogenem Einfluß

*) Anschrift des Verfassers: Prof. Dr. W. SCHIRMER, Abteilung Geologie der Heinrich-Heine-Universität, Universitätsstr. 1, 40225 Düsseldorf
(Hangbearbeitung, Beweidung) gesellt sich kolluviale Bewegung hinzu. Sturzschutt und äolische Sedimentation sind sehr untergeordnet.

Der Aufschlußs Kalavaós-Márcou (Abb. 1), eine Hangfußakkumulation, erschließt rhythmisch geschichteten Havara mit gradierter Schichtung von grob-unten zu fein-oben mit jeweiligem humosen Bodenabschluß (schwache Rendzina). Zwei solcher Böden ergaben ein 14C-Alter an Holzkohlen von 31.970 a BP im tieferen Profilteil und 27.440 a BP im höheren Profilteil (Abb. 2), also ein Alter des Mittelwürms 4 sensu Schirmer 1991 (Tab. 1). Die terrestrische Havara-Boden-Abfolge drängt zum Vergleich mit den Löß-Boden-Rhythmen im Mittelwürm des Schwalbenbergs am Mittelrhein, die ihrerseits weltweit mit Klimarhythmen aus Eiskernen und Tiefseesedimenten korrelierbar sind (SCHIRMER 1995: 531).

Aus der Tatsache, daß Havara heute in viel geringerem Maße, und dann meist durch anthropogene Rodung bedingt, abgelagert wird, und aus der Wechselfolge von Havara und Interstadialböden in mächtigen Havarapaketen läßt sich für die Havara-Bildung eine vegetationsärmere Zeit folgern als die heutige in Zypern. Der weltweite Klimawechsel Stadial/Interstadial findet also auch im terrestrischen Bereich des östlichen Mittelmeerraumes seinen Niederschlag durch vermehrte Hangaktivität mit Schuttproduktion in den Stadialen und Bodenbildung in den Interstadialen.

Im Unterschied zu Havara ist Kafkalla ein Ergebnis der Bodenbildung: Kalkkrusten, Caliche. Sie entstehen durch deszendente Kalkfällung als Kalkknollen und Kalkstangen (Cc-Horizont), vorwiegend aber durch aszendente Kalkverkrustung der Oberfläche und schließlich lateralen Kalktransport in seicht gelegenen Grobsedimenten.

\section{Introduction}

Havara is one of the most widely spread surficial deposits in Cyprus. It occurs predominantly in the limestone areas of Cyprus outside of the Troodos ophiolite area. It is a white to buff, fine, chalky, porous silty powder, which is always mixed with rounded or angular heterolithic bigger clasts although limestone predominates. Havara is used in Cyprus for road metal. Its silt with rock fragments is mixed with water and is spread on top of the surface of roads. During rains it does not turn into slurry - due to its only small content of clay 
minerals. The $\mathrm{CaCO}_{3}$ content of havara, based on eight samples geographically spread over Cyprus, varies from 75-91\% (PANTAZIS 1973: 21).

The origin of havara in Cyprus has been subject of a prolonged discussion. Bellamy \& JuKEs-BrownE (1905: 44) described it as "a calcareous tufa combined with fine pebbles to make a material known as ,khavara', the local term for gravel”. Hence, BELLAMY \& JuKES-BROwNE interprete havara as a sedimentary deposit. Later workers confused havara with kafkalla, the local name for caliche, e. g. BeAR (1960a: 12): "In many places it is difficult to distinguish" Koronia reef limestone "from havara (calcrete)". Wilson (1957: 26) states: "A secondary surface limestone or havara forms a crust". Other workers separated havara and kafkalla lithologically, but interpreted them as having the same origin - the evaporation of calcium carbonate (BEAR 1960b: 42, Gass 1960: 59). PANTAZIS (1973)1) analyzed havara samples from different sites in Cyprus in detail and concluded in concurrence with the earlier workers BelLamy \& JUKES-BROWNE (1905) that havara was a sedimentary deposit, a "terrestrial (fresh water) deposit" (Pantazis 1973: 39). However, Pantazis does not discuss his assertion that havara is a fresh-water deposit. - See Addendum.

In this paper the results of recent studies of numerous outcrops of havara in the southern and western circum-Troodos area are described.

\section{Occurrence of havara 1.1 The depositional environments of havara}

Havara is a terrestrial deposit forming the surficial mantle of limestone-marl areas. It occurs at least in the following geomorphic situations:

a) Slope debris: Along the toes of slopes in limestone uplands havara can accumulate up to a few meters in thickness. In this environment it displays a disordered mixture of limestone fragments and sand-silt components. In some sections, indistinct and discontinuous bedding can be found. The bigger fragments show a slope parallel orientation, sometimes with imbrication dipping upslope.

An example of slope-debris havara is described in the Kalavasós Márcou section below.

b) Debris cones. At the toe of slope concavities, the exit of dales or small valleys thick debris cones form large aprons consisting through and

1) This paper is based on a former unpublished report of T. M. PANTAZIS: A study of some havara and kafkalla samples of Cyprus. - 32 p., 1 map; Nicosia (Ministry of Agriculture) 1961. through of havara. In the debris cones havara displays better bedding, caused by an alternation of stone-free to stone-rich havara. Stone-rich havara exhibits good imbrication of flattened rock fragments dipping upslope. In vicinity to river terraces the rock fragments are also rounded to gravel. Most of the havara exploited in Cyprus comes from debris cones.

c) Surficial veneer. In many places the havara simply occurs as a surface veneer on horizontal or gently inclined geomorphic surfaces. In this type of occurence the silty-sandy grain size of havara is dominant with rock fragments or gravel being subordinate.

\subsection{The Kalavasós Márkou Site}

The site is a slope-cut behind the house of Charálampos Varélla in Kalavasós 150 m south of the church (arrow in Fig.1). It lies $30 \mathrm{~m}$ above the valley bottom at the first flattening of the slope toe. The full place name of this slope is Spilios tou Papá Márkou, the caves of Father Márkou. Here the name is abbreviated to Márkouं2). A section from this site (see Fig.2) is described as follows:

$$
\begin{array}{lll}
\mathrm{cm} & \text { soil description } \\
& \text { symbol[3] } & \\
& & \text { surface: garrigue vegetation }
\end{array}
$$

15 Ah Havara: loam, silty, porous, often powdery, medium- to coarse-stony, rare boulders, scarce small ophiolite pebbles; loose, grey, humic, not stratified, perforated by burrows. Anthropogene colluvium with autochthonous surface soil

140 M Havara: loam, silty, porous to powdery, medium- to coarse-stony, rare boulders, scarce small ophiolite pebbles; brown, not stratified, perforated by burrows. - Anthropogene colluvium

80 C Havara: silt, yellow-white, mediumto coarse-stony, scarce boulders; alternating with irregular, less stony layers; inconspicuous bedding. $20 \mathrm{~cm}$ above the lower contact a $20 \mathrm{~cm}$ long humus-charcoal streak. Radiocarbon age of the charcoal: Hv 19 672: $27440 \pm 1600$ a BP 20 fAh Upper Tsiáko Soil4): silt, yellowish grey-brown, porous, medium-stony, scarce coarse- to boulder-stony, very rare ophiolite pebbles, locally humic

2) deutsch: Márku

3) Soil symbols after FAO (1990). Additionally, M horizon (AG Boden 1994: 102) as migrated soil material is added 
70 C Havara: silt, white-grey, medium-to coarse-stony (Lefkara limestone, sharp-edged, scarce ophiolite pebbles up to $40 \mathrm{~cm}$, partly broken. In the upper part occasionally humic streaks with scarce charcoal

20 fAh Lower Tsiáko Soil: silt, brown-grey, weakly fine- to medium-stony, rare coarse stones and ophiolite pebbles, scarce charcoal

180 C Havara: silt, white-grey, medium- to coarse-stony, scarce boulders, sparse ophiolite pebbles, inconspicuous and irregular bedding. Stones horizontally bedded, but occasionally also vertically orientated

130 fah Gondéssa Soil: silt, light brown to brown-grey, humic to strong humic, slightly fine- to medium-stony, scarce medium- to coarse-stony streaks, scarce ophiolite gravels, lime pseudomycelium, nested charcoal. In one place a $10 \mathrm{~cm}$ large slab of blackbrown baked humic soil with reddish aureole. Radiocarbon age of charcoal Hv 19 262: $31970 \pm 910$ a BP

50 C Havara: silt, white-grey, powdery to porous, strong medium- to coarsestony, boulders, occasional ophiolite pebbles

base not exposed

The Lower and Upper Tsiáko Soils merge up slope forming one Tsiáko Soil (Fig. 2). The lower contact of the Gondéssa Soil was only exposed in a small pit excavated at the bottom of the section (Fig. 2). The soils have fewer coarse clasts than the havara and are also enriched in humus. The soils represent distinct quiescence phases of slope erosion activity. The baked soil slab in the Gondéssa Soil is possibly indicative of human occupance.

\section{Origin of havara}

The occurence of havara as slope debris, debris cones and surficial veneer as described above provides evidence of the differing origin of havara. The bulk of the havara has a colluvial respectively deluvial5) origin. Hill wash processes transport the fines and some of the coarse clasts

\footnotetext{
$\left.{ }^{4}\right)$ pronounce: Chako, deutsch: Tschako. The Tsiáko and Gondéssa Soils are named after the two dogs housed at the toe of the wall. They had to suffer from my wallscratching that produced rockfall on the roof of their huts. Only the promise of scientific fame could console them. 5) term colluvial equals the German term deluvial, also the term abluvial (LiedtKe in Galbas et al. 1980: 10), whilst the German kolluvial is restricted to down slope transport of soil material, mostly induced by man's impact onto the landscape.
}

downslope. In places, the fragments occur as distinct beds well-stratified into coarser and finer layers, the coarser layers occasionally being imbricated; this form of stratification occurs typically in debris cones. In other places, stratification is absent and the coarse and fine material is unsorted.

At the toe of steep slopes there can be rock fragments originating from rock falls producing a lithologic result of isolated large rock fragments within pure fine havara beds.

The large amount of rock fragments, often up to some decimeters in diameter, cannot solely be explained by hillwash and rock fall processes, because there are many areas where rockfall can be excluded. Therefore, it is argued, that soil creep processes play a major role in the formation of these poorly sorted deposits.

Where deposits of fine havara are found they lack any stratification and exhibit porosity and other characteristics similar to loess. This suggests the idea of an eolian origin. On the other hand, however, secondary recrystallisation of the lime within the havara may have destroyed primary lamination. Little eolian component might occur. However, big dust storms, as they occur in cold and or warm arid areas, can be excluded as trigger for havara deposition. Otherwise white havara should cover the dark, widely exposed ophiolite rocks, at least those adjacent to the limy or marly areas, but this is not the case.

\section{Climatic background of the havara formation}

Colluvial processes on slopes of notable amount as they occur in havara piles - as well as eolian processes and solifluction need a landscape less vegetated than today. Additionally these processes need a certain periodical frost scattering thus supplying the slopes with scree to be transported down slope. The requirement for frost activity in Cyprus uplands means a climate colder than today.

All these processes, colluvial, soil creep, rock fall and eolian, do occur, of course, nowadays in Cyprus, especially where the forested landscape has been cleared. Colluvial processes require rainfall that happens during the winter and in the Troodos area sometimes throughout the year. Moreover, colluvial processes need prevention from water seepage. This happens under conditions of extreme water supply, water-oversaturation, extreme dryness of the soil, but also permafrost. Only the former three cases are realized in present Cyprus albeit rarely. Thus, conditions 


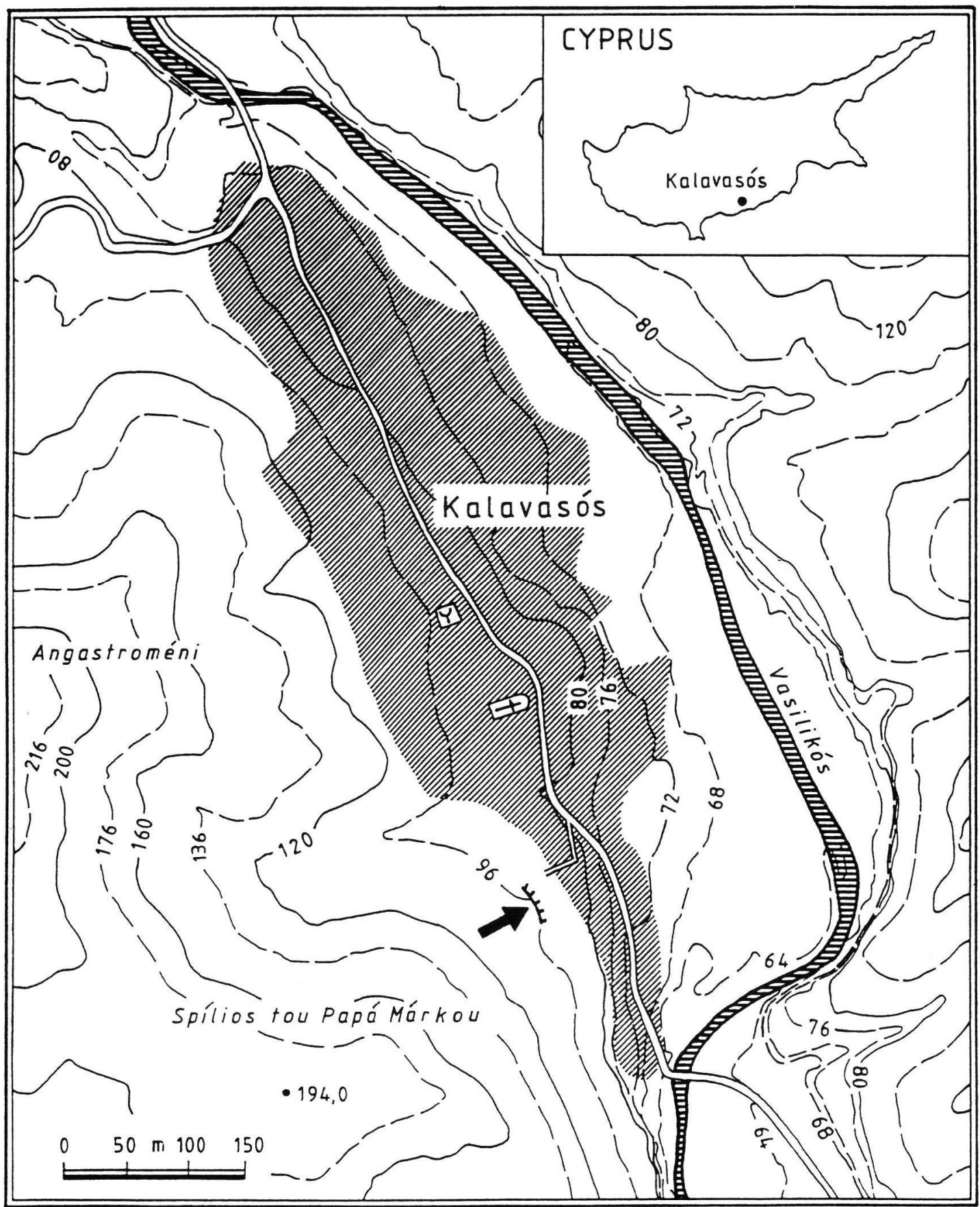

Fig. 1: Location map of the Kalavasós Márcou Site (the arrow marks the site)

Abb. 1: Lageplan des Kalavasós-Márcou-Aufschlusses (der Pfeil markiert den Aufschluß)

for recent colluvial processes are not very frequent but do exist. Furthermore, where the land is cleared on limy soft rocks, that are easily erodable, a solid kafkalla crust (caliche) prevents the soft lime material from being washed off. Thus, modern colluvial deposits concentrate preferably to ravines and along the thalweg of dry valleys. Soil creep processes do not necessarily imply permafrost conditions as it is the case in the periglacial zone. But strong intermittent frost periods as well as water-oversaturated soil effect soil creep. However, these are rare situations in recent times 


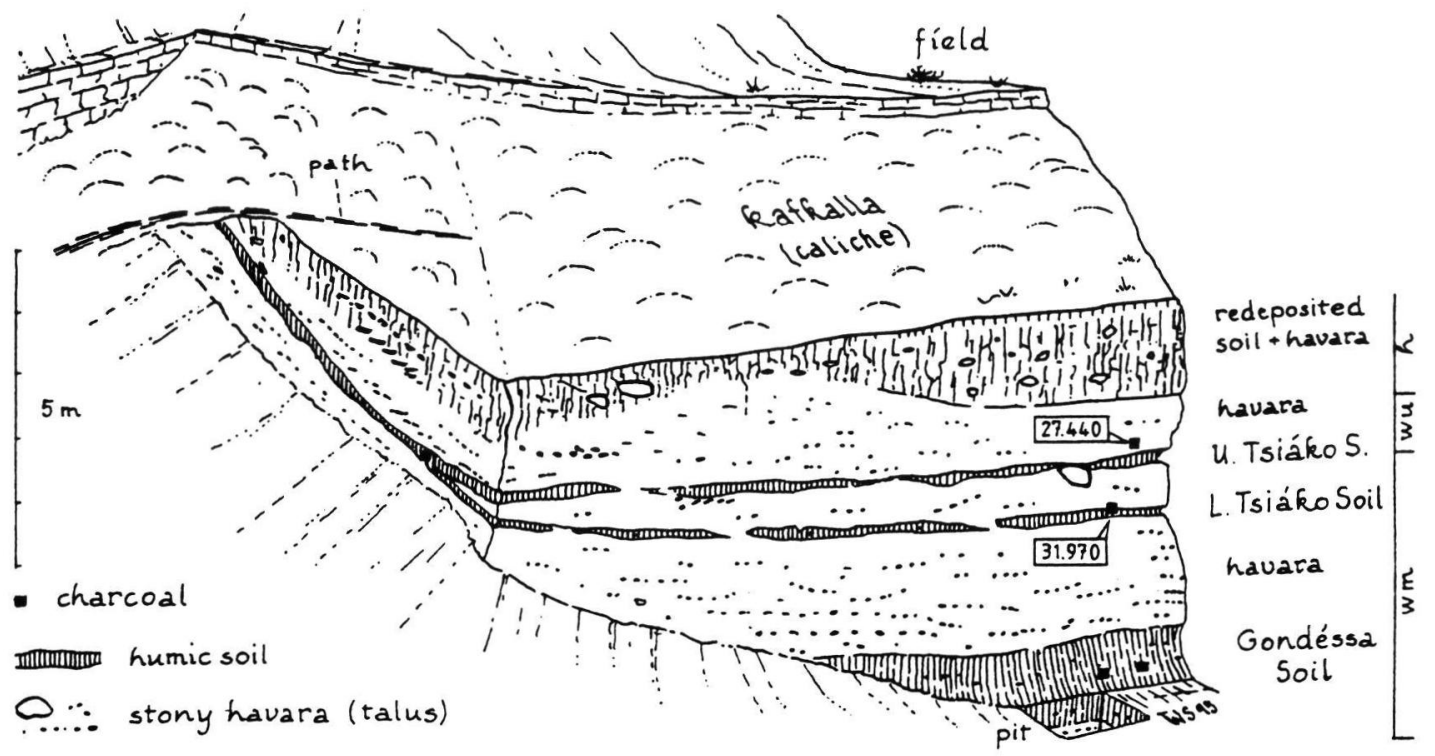

Fig. 2: Sketch of the Kalavasós Márcou Site showing the presence of fossil soils of Middle Würmian age within the havara (silt-rich calcareous talus). Horizontal scale is approximate. $\mathrm{wm}=$ Middle Würmian, wu $=$ Upper Würmian, $\mathrm{h}=$ Holocene

Abb. 2 Skizze des Kalavasós-Márcou-Aufschlusses mit fossilen Mittelwürm-Böden im Havara (siltreicher Kalkhangschutt). Horizontalerstreckung nicht maßstabsgetreu. $w m=$ Mittelwürm, wu $=$ Oberwürm, $h=$ Holozän

and cannot give rise to major and extended soil creep masses.

Recent rockfalls have occured where there is sheep and goat grazing on cleared slopes or by human use of the slopes. Occasionally, rockfalls augment rock debris at the toe of a slope conspicuously.

Recent eolian processes occur in Cyprus. During the wet season a certain amount of raindust from outside Cyprus is spread over the island; the colour of this allochthonous silty dust is yellow to red brown. During dry periods, autochthonous dust can also be blown around on the island, but as rocks adjacent to limestones are free of remarkable coats of lime dust, then the amount of recent local blown lime dust has to be negligible. The modern landscape is not greatly affected by all these processes even though the forest cover has been largely removed. Otherwise the recent surface covered by kafkalla crust would become covered by havara. In other words, in the geomorphic context of recent slope erosion activity as shown presented by the havara exposures, the erosional debris production would have covered repeatedly the surficial kafkalla crust in such a way that there would exist a series of buried kafkalla horizons - but this is not the case.

As the landscape is now largely deforested, yet extensive active slope processes are lacking, then the landscape at times when havara formed must have been more open than today. This requires a colder climate than that today. Consequently, most of the havara must have been deposited during colder climate than that existing today.

\section{Age of havara}

The data gained from the Kalavasós Márcou section (Fig. 2), as well as the thick and fine-grained havara beds, deposited under scattered vegetation and increased frost activity, lead to the conclusion that most of the exposed havara is of Würmian age:

1,5 m kafkalla formation (displayed in Fig. 2): anthropogene Holocene

$\sim 1,5 \mathrm{~m}$ humic soil formation: forested Holocene

2,0 m upper havara: Upper Würmian

$\sim$ 4,5 m Tsiáko-Gondéssa havara: Middle Würmian 46) lower havara

It is concluded that most of the havara is of a glacial age, and a lesser amount was produced du-

6) SCHIRMER (1991, 1995) subdivides the Middle Würmian (MW) loess of Germany into four sections: MW 1 represents the could O-stage 4, MW 2-4 the warmer O-stage 3 with eight interstadial soils and a conspicuous intermittent cooling phase (MW 3) (see Tab. 1) 


\begin{tabular}{|c|c|c|}
\hline Section & Lithology & Depositional environment \\
\hline & and so on..... & \\
\hline & havara with rock fragments & hill wash and soil creep ( \pm little eolian activity) \\
\hline & _-unconformity. & strong slope erosion \\
\hline & soil formation & vegetation growth \\
\hline & fine havara & gentle hillwash ( \pm little eolian activity) \\
\hline & havara with rock fragments & hill wash and soil creep ( \pm little eolian activity) \\
\hline
\end{tabular}

Fig. 3: Rhythmicity within the depositional sequence of havara deposits (calcareous talus) and soils in Cyprus

Abb. 3: Ablagerungsrhythmus innerhalb der Havara (Kalkhangschutt)-Boden-Folgen in Zypern

Tab.1: Middle Würmian of the Central European periglacial area and Cyprus

Tab. 1: Mittel-Würm des mitteleuropäischen Periglazialgebietes und Zyperns

\begin{tabular}{|c|c|c|c|}
\hline O-stages & Stage & Central European periglacial area & $\begin{array}{c}\text { Cyprus } \\
\text { (Kalavasós Márcou Site) }\end{array}$ \\
\hline 2 & $\begin{array}{c}\text { Upper } \\
\text { Würmian }\end{array}$ & loess & havara \\
\hline 3 & $\begin{array}{l}\text { Middle } \\
\text { Würmian }\end{array}$ & $\begin{array}{l}\text { Sinzig soils 1-3: calcic cambisols } \\
\text { Kripp stadial: loess } \\
\text { Remagen soils 1-5: calcic cambisols } \\
\text { stadial: loess }\end{array}$ & $\begin{array}{l}\text { Tsiáko-Gondéssa soils } \\
\text { (3 soils): calcic regosols } \\
\text { havara }\end{array}$ \\
\hline
\end{tabular}

ring a warm climatic period. A certain share is due to reworking of the havara and redeposition under deforested Holocene conditions.

\section{Rhythmicity within havara deposition}

Sections through the havara show the depositional sequence schematically drawn in Fig. 3. This rhythmicity of slope development points to a climate process starting with strong erosional activity that later tapers off and is eventually totaly lacking during periods of active vegetational growth with its accompanying soil formation.

\section{Havara formation and climate course}

The soil units within the Kalavasós Márcou section demonstrate the stadial/interstadial rhythms, known from the periglacial areas, likewise to be well developed in the eastern Mediterranean. The Middle Würmian of the Central European perigla- cial area is subdivided by at most eight fossil soils (SCHIRmer 1991, 1995), alternating with loess and loess derivates (Tab. 1). I am far from assuming the three Kalavasós Márcou soils to correspond to the three Sinzig Soils listed up in Tab. 1, but the Central European soil sequences provide a potential model for correlation. However, for such a correlation the Kalavasós Márcou Site is, firstly, too limited in exposure though, presumably, the rhythmical sequence continues at depth. Secondly, neither the dates of the Sinzig Soils nor that of the Tsiáko-Gondéssa Soils are reliable enough to correlate both soil by soil. The only fact to follow is the Kalavasós Márcou Site to assign to the Middle Würmian 4 sensu SCHIRMER 1991, that is the upper part of O-stage 3.

In the Kalavasós Márcou section the havara takes the position of the periglacial loess, and the calcic regosols in Cyprus take the position of the calcic cambisols of the periglacial zone. The difference 
between cambic soils in the loess and regosols in the havara is due to a higher clay content of the loess and a less one in the havara.

The morphogenetic relationships are similar in both areas - the periglacial area of central Europe and the eastern Mediterranean:

During stadials, there were unstable conditions with slope forming processes under scattered vegetation in Cyprus, and loess-steppe with solifluction in the periglacial zone. During interstadials, stable conditions existed with a vegetation cover (? forest) in Cyprus, and similar stable conditions but with shrub tundra in the periglacial zone. No doubt, there was a difference in climatic conditions and vegetative zones between the periglacial area and Cyprus. However, during the course of a glacial cycle the principal geomorphic conditions and the process rhythmicity turn out to be comparable between both the eastern Mediterranean and the Central European periglacial zone.

To argue against the former opinion the debris masses to origin during strong rainfall under "pluvial" conditions, and the soils to origin under drier "interpluvial" conditions7), it is pointed out that the debris deposits lack considerable shares of soil material (for example humic streaks) that is to be expected in case of strong hill wash processes under warm conditions with an extensive vegetation cover.

\section{Slope development and debris accumulation}

The Kalavasós Márkou section demonstrates the main phases of debris production to be assigned to stadial phases of a glacial period. Consequently, the extended debris fans flanking the river valleys in Cyprus have to be regarded as result of stadial conditions; these conditions are characterized by less vegetation than in the Holocene. Further, it is suggested that stronger frost activity was also a major factor during glacial periods. Today, on Mount Olympos (1956 m), the highest elevation of Cyprus, frost polygons and solifluction lobes are developing in areas with scattered vegetation. Every year from end of November to the beginning of April several tens of freeze-thaw transitions occur on this summit.8) During Würmian stadial conditions the lower frost limit was much lower, and when combined with a lack

7) see pluvial/interpluvial discussion in SCHWARZBACH (1993: 224)

8) according to temperature measurements of the Meteorological Service of Cyprus of vegetation, then conditions of debris production would have been more intensive throughout Cyprus.

These results coincide with the conclusions of IoAKIM \& CHRISTANIS (1997: 102) who follow for the Greek mountains from palynological evidences an "open steppe-like vegetation" for the cold phases of the last glacial-interglacial cycle. HempeL (1990: 80) also found in the mountain areas of Crete and southern Greece that the main phases of debris deposition were of glacial age. He attributes, however, the bulk of debris to Saalian, rather than Würmian age.

\section{Relationship of havara and kafkalla}

Kafkalla is the local term for caliche, calcrete or petrocalcic horizon (SOIL SURVEY STAFF 1992: 20). Genetically the kafkalla horizons belong to soil formation, because there is no kafkalla deposition but rather kafkalla precipitation. The Cyprean kafkalla is an enrichment of lime within the solum that occurs in three ways:

a) Descendent lime precipitation starting with calcaric nodules within and below the $\mathrm{B}$ horizon;

b) Ascendent lime precipation forming the calcaric crusts on top of the surface;

c) Lateral lime precipitation by groundwater movement.

Each of these processes effects a hardening of the soil. Although all three processes interact in forming kafkalla, it is the ascendent origin that has the dominant role.

Bellamy \& Jukes-Browne (1905: 43) give a reasonably good description of kafkalla with an essenti-. ally correct explanation of its origin, although they term it capstone and do not use the name kafkalla.

Normally a surficial kafkalla crust is hardest at the top and merges downward into a softer material, which may resemble havara. Therefore, the delimination of both rock types becomes difficult especially in those cases when kafkalla has been formed on top of havara. This may be a major reason for the different opinions regarding the genesis of havara and kafkalla by the authors quoted in the beginning of this paper.

Kafkalla occurs rarely prior to the Holocene. PreHolocene soils exhibit mostly descendent Bc horizons, and they lack the ascendent component. Therefore, it is concluded, that the dominant ascendent lime precipitation of the recent surface is mainly due to land clearance in the Holocene. Thus, kafkalla formation needs a surface free of vegetation to some extent. Kafkalla does not pass 
laterally into havara. The formation of both does not happen simultaneously in the same place even though both need a restricted vegetation cover. During periods of havara formation evaporation was not enough to form kafkalla. Thus, kafkalla needs little vegetation and a warm climate to cause high evaporation rates. Under natural (preclearance) conditions on Cyprus, warm climate encourages vegetation growth, and vegetation reduces evaporation from the soil and precludes kafkalla formation. Consequently, it is concluded that land clearance under Holocene conditions was the main cause for the formation of kafkalla.

\section{Acknowledgements}

I am grateful to a number of people for their assistance: Charálampos and PANageióta Varélla, Kalavasós, gave access to the outcrop on their land. Mélis Violári, Kalavasós, was so helpful to store my tools over all the time of my field work in Cyprus. Dr. Costas Xenophontos, Geological Survey of Cyprus, Nicosia, provided me with maps and literature. K. L. Philaniotis, Meteorological Service of Cyprus provided me with climatic data of Mount Olympus. My wife Ursula gave me valuable support during field work and discussions. Prof. Dr. Michael RoberTs, Department of Geography of the Simon Fraser University in Burnaby, Canada, was so kind to review the text and its English language.

\section{Literature}

AG BODEN (1994): Bodenkundliche Kartieranleitung, 4. Aufl., 392 S.; Hannover (BGR).

Bear, L. M. (1960a): The geology of the PeristeronaAngolemi area. - Mem. Geol. Surv. Dept. Cyprus, 2: 8-20, 1 geol. map 1: 31680; [Nicosia].

- (1960b): The geology and mineral resources of the Akaki-Lythrodondha area. - Mem. Geol. Surv. Dept. Cyprus, 3: 122 p.; 1 geol. map 1: 31680; [Nicosia].

Bellamy, C. V. \& Jukes-Browne, A. J. (1905): The geology of Cyprus. - 72 p.; Plymouth (W. Brendon \& Son).

FAO-UNESCO (1990): Soil map of the world. Revised legend. - World soil resources report, 60: 119 p.; Rome.

Galbas, P. U., Klecker, P. M. \& LiedtKe, H. (1980): Erläuterungen zur Geomorphologischen Karte 1: 25000 der Bundesrepublik Deutschland, GMK 25, Blatt 5, 3415 Damme. - 48 p.; Berlin.
GASS, I. G. (1960): The geology and mineral resources of the Dhali area. - Mem. Geol. Surv. Dept. Cyprus, 4: 116 p.; 1 map 1:31680; [Nicosia].

Hempel, L. (1990): Klima- und Landschaftsgenese der östlichen Mediterraneis im Jungquartär. - Colloquium Geographicum, 20: 59-84; Bonn.

IOAKIM, C. \& CHRISTANIS, K. (1997): Late Quaternary of a peat profile from the Kalodiki peatland in Epirus, Western Greece: Sedimentary and vegetational history. - Z. dt. geol. Ges., 148 (1): 95-104; Stuttgart.

PANTAZIS, T. M. (1973): A study of the secondary limestones (Havara and Kafkalla) of Cyprus. - Geographical Chronicles, 2 (4): 12-39; Nicosia.

SCHIRmer, W. (1991): Würmzeitliche Paläoböden am Mittelrhein. - 10. Tagung des Arbeitskreises Paläoböden der Deutschen Bodenkundl. Ges. vom 30. 5. - 1. 6. 1991 in Bonn, Programm und Exkursionsführer: 70-83; Münster.

- (1995): Schwalbenberg/Remagen, Middle Würmian. - In: SCHIRMER, W. [ed.]: Quaternary field trips in Central Europe, 1: 530-532; München (Pfeil)

Schwarzbach, M. (1993): Das Klima der Vorzeit. Eine Einführung in die Paläoklimatologie. - 5. Aufl., 380 S.; Stuttgart (Enke).

SOIL SURVEY STAFF (1992): Keys to soil taxonomy. - 5. edition, Soil Management Support Services (SMSS) technical monograph, 19: 541 p.; Blacksburg, Virginia (Pocahontas).

Wilson, R. A. M. (1957): Progress report. - Annual Report Geol. Surv. Dept. Cyprus 1956: 23-27, Fig. 3; Nicosia.

\section{Addendum}

Mrs. Nfrgis Akçora, Turkologist, Düsseldorf, was so kind to give me information about the RedHouse Turkish-English-Lexicon that lists the term havara. In the edition of 1921 (page 810) „hawwara" is listed to have the meaning of "white flour, fine flour". After the edition of 1968 (page 464) the term "havara" is derived from Arabic and is provincially used for a "kind of soft building stone“ and „whitewash“., These explanations of both editions match highly with the definition and description of the soft, surficial rock havara given in the foregoing text. The meaning of the 1921 edition reflects the fine, powdery consistence of the rock havara. That of the 1968 edition points to the use of the rock havara.

Redhouse, J. W. (1921): A Turkish and English Lexicon; Constantinople (H. Matteosian).

- (1968): New Redhouse Turkish-English dictionary. 1292 p.; Istanbul (Redhouse Press).

Manuskript eingegangen am: 28. August 1997 